\title{
Could COVID-19 be a latent viral infection?
}

\author{
Sergey Sheleg* and Alexey Vasilevsky \\ Phoenix VA Health Care System, 650 E Indian School Rd, Phoenix, AZ 85012, USA
}

Received: 21 April, 2020

Accepted: 04 June, 2020

Published: 05 June, 2020

*Corresponding author: Sergey Sheleg, MD, Phoenix VA Health Care System, 650 E Indian School Rd, Phoenix, AZ 85012, USA, E-mail: ssheleg@yahoo.com

Keywords: SARS-CoV-2; COVID-19; Anosmia; Latent infection

https://www.peertechz.com

Check for updates

\section{Dear Editor}

COVID-19, a respiratory illness caused by a novel coronavirus, spread globally and emerged more than 6 million people by the beginning of June 2020 .

Recently South Korean officials reported that nearly 100 people thought to be cured of the novel coronavirus have tested positive for COVID-19 again. Per Jeong Eun-kyeong, director of the Korea Centers for Disease Control and Prevention, the COVID-19 virus may have "reactivated" in the patients rather than them becoming re-infected [1].

A latent viral infection is an infection that is inactive or dormant. As opposed to active infections, where a virus is actively replicating and potentially causing symptoms, latent (or persistent; but not chronic) infections are essentially static which last the life of the host and occur when the primary infection is not cleared by the adaptive immune response [2]. Herpes simplex viruses type 1 and 2, varicella-zoster virus, HIV, Epstein-Barr virus (human herpesvirus 4), and cytomegalovirus are examples of viruses that are well known to cause typical latent infections in human [3-5].

Latent viral infections can be reactivated into a lytic form (the replication of a viral genome). The ability to move back and forth from latent to lytic infections helps the virus spread from infected individuals to uninfected individuals [6].

The brain is in many ways an immunologically and pharmacologically privileged site. The blood-brain barrier (BBB) restricts access of immune cells and immune mediators to the central nervous system (CNS) [7].

Anosmia has been reported in conjunction with wellreported symptoms of COVID-19 [8]. By Lechien, et al. (2020), anosmia even appeared before the other symptoms in $11.8 \%$ of COVID-19 cases [9].
Rabies is a fatal zoonotic neuroinfectious disorder caused by the RNA virus. It's well known that the rabies virus may cause a latent infection in both animals (commonly in bats) and human $[10,11]$.

Could the SARS-CoV-2 virus (causative RNA virus for human COVID-19, which is currently thought to be an animal virus from an as-yet-uncertain animal reservoir, perhaps bats) be another latent viral infection by means of cytoplasmic episomal latency mechanism in the neurons of olfactory tract given the well-known fact that the BBB limits the entry of immune cells and immune mediators into the CNS that may prevent from eradication of this infection?

\section{References}

1. (2020) South Korea reports recovered coronavirus patients testing positive again. Link: https://reut.rs/3gGs6wO

2. Stroop WG, Baringer JR (1982) Persistent, slow and latent viral infections. Prog Med Virol 28: 1-43. Link: https://bit.ly/3gMZ8ey

3. Jordan MC, Jordan GW, Stevens JG, Miller G (1984) Latent herpesviruses of humans. Ann Intern Med 100: 866-880. Link: https://bit.ly/3gJmmCl

4. Fauci AS (1988) The human immunodeficiency virus: infectivity and mechanisms of pathogenesis. Science. 1988;239:617-622. Link: https://bit.ly/3dquQfO

5. Stern H (1972) Cytomegalovirus: A cause of persistent latent infection. J Clin Pathol Suppl (R Coll Pathol) 6: 34-38. Link: https://bit.ly/2Bpakhu

6. Traylen CM, Patel HR, Fondaw W, Mahatme S, Williams JF, et al. (2011) Virus reactivation: a panoramic view in human infections. Future Virol 6: 451-463. Link: https://bit.ly/3eHdbAF

7. Muldoon LL, Alvarez Jl, Begley DJ, Boado RJ, del Zoppo GJ, et al. (2013) Immunologic privilege in the central nervous system and the blood-brain barrier. J Cereb Blood Flow Metab 33: 13-21. Link: https://bit.ly/3dry5n1

8. Vaira LA, Salzano G, Deiana G, De Riu G (2020) Anosmia and ageusia: common findings in COVID-19 patients. Laryngoscope. Link: https://bit.ly/3eJcJ4K 
9. Lechien JR, Chiesa-Estomba CM, De Siati DR, Horoi M, Le Bon SD, et al. (2020) Olfactory and gustatory dysfunctions as a clinical presentation of mild-to-moderate forms of the coronavirus disease (COVID-19): a multicenter European study. Eur Arch Otorhinolaryngol. Link: https://bit.ly/3gQUsET

10. Sulkin SE (1962) Bat rabies: experimental demonstration of the "reservoiring mechanism". Am J Public Health Nations Health 52: 489-498. Link: https://bit.ly/2Mkm8nl

11. Smith JS, Fishbein DB, Rupprecht CE, Clark K (1991) Unexplained rabies in three immigrants in the United States. A virologic investigation. N Engl J Med 324: 205-211. Link: https://bit.ly/2XTMl10

\section{Discover a bigger Impact and Visibility of your article publication with}

\section{Peertechz Publications}

\section{Highlights}

* Signatory publisher of ORCID

* Signatory Publisher of DORA (San Francisco Declaration on Research Assessment)

* Articles archived in worlds' renowned service providers such as Portico, CNKI, AGRIS, TDNet, Base (Bielefeld University Library), CrossRef, Scilit, J-Gate etc.

* Journals indexed in ICMJE, SHERPA/ROMEO, Google Scholar etc.

- OAI-PMH (Open Archives Initiative Protocol for Metadata Harvesting)

* Dedicated Editorial Board for every journal

* Accurate and rapid peer-review process

* Increased citations of published articles through promotions

* Reduced timeline for article publication

Submit your articles and experience a new surge in publication services (https://www.peertechz.com/submission).

Peertechz journals wishes everlasting success in your every endeavours.

Copyright: $\odot 2020$ Sheleg S,et al. This is an open-access article distributed under the terms of the Creative Commons Attribution License, which permits unrestricted use distribution, and reproduction in any medium, provided the original author and source are credited. 